\title{
INFLUENCE OF CHUNKY GRAPHITE ON LATENT HEAT
}

\author{
VPLIV CHUNKY GRAFITA NA LATENTNO TOPLOTO
}

\author{
Ivana Mihalic Pokopec ${ }^{1}$, Primož Mrvar ${ }^{2}$, Branko Bauer ${ }^{1}$ \\ ${ }^{1}$ University of Zagreb, Faculty of Mechanical Engineering and Naval Architecture, Ivana Lucica 5, 10002 Zagreb, Croatia \\ ${ }^{2}$ University of Ljubljana, Faculty of Natural Science and Engineering, Lepi pot 1, 1000 Ljubljana, Slovenia \\ branko.bauer@fssb.hr \\ Prejem rokopisa - received: 2017-07-21; sprejem za objavo - accepted for publication: 2017-10-02
}

doi: $10.17222 / \mathrm{mit} .2017 .122$

\begin{abstract}
The study presents the results of investigations of the thermal effects that take place during the heating and cooling of samples of the spheroidal graphite cast iron with different amounts of chunky graphite (CHG) in the microstructure. In order to obtain a different amount of CHG, cone blocks $\Phi 300 \mathrm{~mm} \times 350 \mathrm{~mm}$ were casted. Two different test melts, EN-GJS-400-18 with $0.7 \%$ of the mass fraction of Ni and EN-GJS-400-15 with $3.5 \%$ of the mass fraction of Si were used. From each block three samples, with different cooling rates, were prepared. For studies of phase transformations, the technique of differential scanning calorimetry (DSC) was used. The microstructure was examined before and after DSC by optical microscopy. The obtained values of the enthalpy of melting and solidification differ and depend on the initial microstructure of the examined samples. The remelting of samples results in magnesium oxidation and significant changes in the eutectic morphology, which, at room temperature, consists of fine and/or coarse undercooled types of graphite with a lamellar morphology.

Keywords: chunky graphite, DSC, graphite morphology, heating and cooling
\end{abstract}

Raziskava predstavlja rezultate toplotnih efektov med segrevanjem in hlajenjem vzorcev iz sive litine s kroglastim grafitom z različnimi deleži chunky grafita $(\mathrm{CHG})$. Z namenom pridobitve različnih deležev chunky grafita, so bili vliti ulitki stožčaste oblike z zgornjim premerom $300 \mathrm{~mm}$ in višino $350 \mathrm{~mm}$. Uporabljeni sta bili dve različni talini, EN-GJS-400-18, z 0,7 masnega $\% \mathrm{Ni}$ in EN-GJS-400-15, s 3,5 masnimi \% Si. Iz vsakega bloka so bili pripravljeni trije vzorci z različnimi ohlajevalnimi hitrostmi. Za raziskave faznih transformacij je bila uporabljena diferenčna vrstična kalorimetrija (DSC). Vzorci so bili preiskani z optično metalografijo pred in po DSC analizi. Izmerjene vrednosti entalpij taljenja in strjevanja se razlikujejo in so odvisne od mikrostrukture preiskanih vzorcev. Posledica pretaljevanja vzorcev je oksidacija magnezija in posledično spremembe v morfologiji evtektika, ki pri sobni temperaturi vsebuje fine in/ali grobe oblike podhlajenega lamelnega grafita.

Ključne besede: chunky grafit, DSC, morfolgija grafita, segrevanje in ohlajanje

\section{INTRODUCTION}

The manufacture of thick-walled castings of spheroidal graphite cast iron represents an area of continuing growth, and this trend is set to continue at least over the next 20 years. This refers primarily to the manufacture of castings for wind farms, manufacture of containers for the permanent storage of nuclear waste and the industry for heavy-duty vehicles. ${ }^{1-6}$ Future applications of thickwalled castings of spheroidal graphite cast irons will require increasingly thicker walls. In parallel, the requirements for mechanical properties will grow too, thus leading to a growing importance of the high-quality spheroidal morphology of the graphite. Every degeneration of graphite, which is a frequent and undesirable phenomenon in the manufacture of thick-walled castings, leads to a decrease of the mechanical properties and very often results in the discarding of such castings. ${ }^{7}$ The most detrimental among these deteriorations is chunky graphite. This defect mainly occurs in the thermal centre of the thick-walled cast parts and causes a decrease in the mechanical properties, especially tensile strength, elongation and fatigue strength..$^{3-10}$

The main causes for the occurrence of $\mathrm{CHG}$ are slow cooling rate and chemical composition. The slower the cooling rate, the greater, the fewer and more irregular the nodules. These conditions favour the formation of $\mathrm{CHG}$. As for the chemical composition, numerous studies have established that $\mathrm{Ce}, \mathrm{Si}, \mathrm{Ni}$ and $\mathrm{Ca}$ promote the formation of chunky graphite. $1,3,5,6,9$

It is well-known that chunky graphite forms during a eutectic reaction. However, there is a disagreement about whether chunky graphite forms in the melt during the early phase of eutectic solidification or on locations of the remaining melt towards the end of the eutectic solidification. Likewise, it is not known whether the spheroidal or chunky graphite forms first.

According to $\mathrm{H}$. Itofuji and $\mathrm{H}$. Uchikava ${ }^{11}$ the formation and growth of chunky graphite occurs in the later phase of eutectic solidification, when the growth of the nodule is almost in its final phase. The formation of chunky graphite in the later phase of eutectic solidification is in line with H. Nakae et al. ${ }^{12}$ According to $\mathrm{Z}$. Zhang et al. ${ }^{13}$ chunky graphite forms in the middle or towards the end of eutectic solidification at the austenite/liquid interface and continues to grow towards the rest of the melt. On the other hand, according to $\mathrm{J}$. Zhou, ${ }^{14,15}$ chunky graphite forms in the initial phase of eutectic solidification. 
The DSC method enables us to follow the phase transformations during the heating and cooling of samples and the enthalpies with reference to reactions during melting and solidification and transformation in the solid state. ${ }^{16,17}$ In this paper, the DSC method was used to determine the characteristic temperatures and enthalpies during heating and cooling. By using samples with a different share of $\mathrm{CHG}$, an attempt was made to identify a relation to solidification enthalpy and the influence of CHG content on newly formed microstructure. In order to analyse more easily and precisely the DSC cooling curves of samples, a metallographic analysis was performed before and after the analysis by an optical microscope.

\section{EXPERIMENTAL PROCEDURE}

Two different test melts were used: EN-GJS-400-18 with $0.7 \%$ of the mass fraction of Ni and EN-GJS400-15 with $3.5 \%$ of the mass fraction of Si.

The test castings used in this study were cone blocks with diameter of $300 \mathrm{~mm}$ and a height of $350 \mathrm{~mm}$, Figure 1, to enable investigation of the influence of different cooling rates on chunky-graphite formation.

Two moulds (M1, M2) were produced from sodium silicate bonded sand. For both moulds, KALPUR direct pouring process was used.

Both test melts were produced in a $5.6 \mathrm{t}$ capacity medium frequency induction furnace. The charge material consisted of grey pig iron (Sorelmetal ${ }^{\circledR}$ ), steel scrap and returns as listed in Table 1. In order to increase carbon and silicon contents and the nucleation ability of the melt, $\mathrm{SiC}(\sim 92 \%$ of the mass fraction of $\mathrm{SiC})$ was added into the furnace with the metallic charge. Also, for increasing Si content, in the second melt $2.3 \%$ of the mass fraction of $\mathrm{FeSi}$ was added. Once melting was finished, the chemical composition of the metal was adjusted according to carbon and silicon evaluation given by thermal analysis and spectrometric analysis on the coupon for the other elements.

For both moulds, the spheroidising treatment was carried out in a dedicated ladle of $200 \mathrm{~kg}$ capacity by adding $\sim 1.8 \%$ of the mass fraction of FeSiMg alloy (44-48 \% of the mass fraction of $\mathrm{Si}, 3.5-3.8 \%$ of the mass fraction of $\mathrm{Mg}, 0.9-1.1 \%$ of the mass fraction of $\mathrm{Ca}, 0.5-1.2 \%$ of the mass fraction of $\mathrm{Al}, 0.6-0.8 \%$ of the mass fraction of RE, Fe bal.) and $0.2 \%$ of the mass fraction of cover alloy (46-50\% of the mass fraction of $\mathrm{Si}, 1.8-2.2 \%$ of the mass fraction of $\mathrm{Ba}, 0.4-0.6 \%$ of the mass fraction of $\mathrm{Ca}, 0.5-1.0 \%$ of the mass fraction
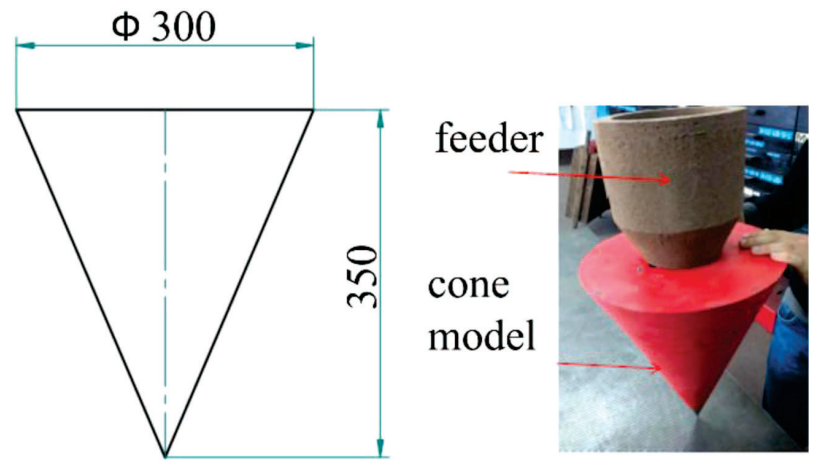

Figure 1: Pattern used in experiment

Table 1: Charge materials used for melting, in mass fractions

\begin{tabular}{|c|c|c|c|c|c|}
\hline Total & $\begin{array}{c}\text { Sorel- } \\
\text { metal }^{\circledR} \\
(w / \%)\end{array}$ & $\begin{array}{c}\text { Returns } \\
(w / \%)\end{array}$ & $\begin{array}{c}\text { Steel } \\
\text { scrap } \\
(w / \%)\end{array}$ & $\begin{array}{c}\mathrm{SiC} \\
(w / \%)\end{array}$ & $\begin{array}{c}\text { FeSi } \\
(w / \%)\end{array}$ \\
\hline $5.6 \mathrm{t}$ & 70 & 21 & 9 & 0.1 & $0.2 *$ \\
\hline
\end{tabular}

$* 2,3(w / \%)$ for $2^{\text {nd }}$ melt

of $\mathrm{Al}, \mathrm{Fe}$ bal.) using the sandwich method at $\sim 1480{ }^{\circ} \mathrm{C}$. The FeSiMg alloy was positioned at the bottom of the casting ladle and then covered by cover alloy before pouring the iron from the furnace. In first casting ladle $0.7 \%$ of the mass fraction of $\mathrm{Ni}$ and in the second casting ladle $0.7 \%$ of the mass fraction of $\mathrm{FeSi}$ was added on the bottom before pouring the iron from the furnace.

After the treatment, slag was removed from the melt surface and the melt was poured into the mould. Holding time was $\sim 3 \mathrm{~min}$. Second inoculation (in-stream) during pouring in the mould was performed by adding $0.45 \%$ of the mass fraction of inoculant containing Ce (70-76\% of the mass fraction of Si, 1.5-2.0\% of the mass fraction of $\mathrm{Ce}, 0.75-1.25 \%$ of the mass fraction of $\mathrm{Al},>1 \%$ of the mass fraction of $\mathrm{O}$ and $\mathrm{S}, \mathrm{Fe}$ bal.). Pouring temperature for both moulds was $1380{ }^{\circ} \mathrm{C}$ and pouring time $27 \mathrm{~s}$.

Just before pouring the melt in the mould, the chilled coupon was analysed by optical emission spectrometer (ARL 3460). C and Si contents were determined from the results of thermal analysis using the $\mathrm{ATAS}^{\circledR}$ system. Chemical composition is listed in Table 2.

Each cylindrical block was afterwards sectioned along the vertical symmetry plane to evaluate the zone affected by CHG, and then one half of each block was sectioned along the horizontal symmetry plane $50 \mathrm{~mm}$ from the base of the cone. From the bottom part of the sectioned cone, the slice of $10 \mathrm{~mm}$ thickness was then taken for sample preparation.

Table 2: Chemical composition of the melts

\begin{tabular}{|c|c|c|c|c|c|c|c|c|c|c|c|c|c|c|c|}
\hline \multirow{2}{*}{$\begin{array}{c}\text { Cone } \\
\text { No. }\end{array}$} & \multicolumn{15}{|c|}{ In mass fractions, $(w / \%)$} \\
\hline & $\mathrm{C}$ & $\mathrm{Si}$ & $\mathrm{Mn}$ & $\mathrm{S}$ & $\mathrm{P}$ & $\mathrm{Mg}$ & Co & $\mathrm{Ni}$ & $\mathrm{Cr}$ & $\mathrm{Cu}$ & $\mathrm{Sn}$ & Mo & $\mathrm{Ti}$ & $\mathrm{Al}$ & $\mathrm{ACEL}^{*}$ \\
\hline 1 & 3.25 & 1.75 & 0.160 & 0.011 & 0.032 & 0.036 & 0.017 & 0.720 & 0.030 & 0.016 & 0.004 & 0.003 & 0.007 & 0.0095 & 4.17 \\
\hline 2 & 2.91 & 3.46 & 0.162 & 0.006 & 0.034 & 0.059 & 0.016 & 0.026 & 0.030 & 0.016 & 0.006 & 0.003 & 0.011 & 0.0247 & 4.24 \\
\hline
\end{tabular}



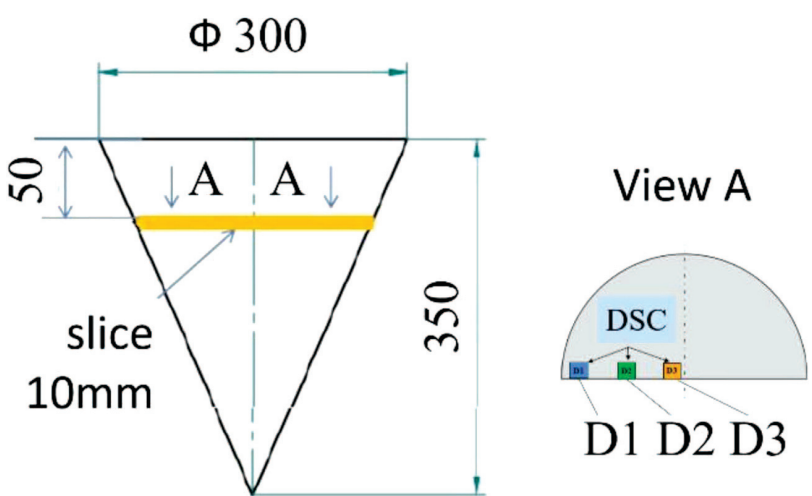

Figure 2: Schematic diagram of sampling for DSC analysis

For DSC, three samples with three different cooling rates (from the edge to the centre) from each slice were prepared, Figure 2. Cooling rates were: $0.036,0.022$ and $0.016{ }^{\circ} \mathrm{C} / \mathrm{s}$. The sampling locations were determined by simulation of the casting and solidification processes. Samples were $\Phi 5 \mathrm{~mm} \times 4 \mathrm{~mm}$ in size. Samples of cone 1 were marked as 1-D1, 2-D2 and 3-D3, and of cone 2 as 2-D1, 2-D2 and 2-D3.

Differential scanning calorimetry or DSC with thermogravimetry was carried out using a simultaneous thermal analyser NETZSCH STA 449 F3 Jupiter® at a cooling/heating rate of $10 \mathrm{~K} / \mathrm{min}$, Figure 3. Holding temperature was $1400{ }^{\circ} \mathrm{C}$ and holding time 1 minute.

The metallographic analysis was done by optical microscope (Olympus BX 61) which was equipped with a system for automatic image processing (Analysis ${ }^{\circledR}$ Materials Research Lab). The samples were etched in a $3 \%$ nital solution. Metallographic analysis was carried out on the same samples for DSC, before and after the calorimetric measurements.

\section{RESULTS}

DSC cooling and heating diagrams of sample 1-D1 taken from cone 1 for the maximum cooling rate are shown in Figure 4. The microstructures before and after

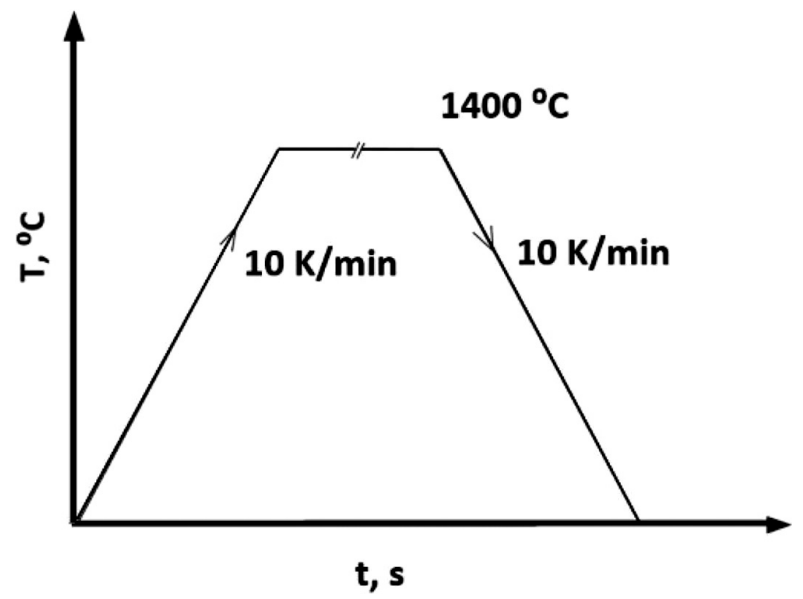

Figure 3: Heating and cooling regime during DSC analysis the conducted DSC analysis for the said sample are shown in Figure 5. Table 3 shows the results of melting and solidification enthalpies and temperatures measured on all samples of cone 1 .

Table 3: Significant temperatures and enthalpies for cone 1, with $0.7 \%$ of the mass fraction of $\mathrm{Ni}$

\begin{tabular}{|c|l|c|c|c|}
\hline \multirow{5}{*}{ Parameter } & \multicolumn{3}{|c|}{ Sample } \\
\cline { 2 - 5 } & & $1-\mathrm{D} 1$ & $1-\mathrm{D} 2$ & $1-\mathrm{D} 3$ \\
\hline \multirow{5}{*}{ Heating } & $T_{\text {Curie }},{ }^{\circ} \mathrm{C}$ & 693 & 693.1 & 690.1 \\
\cline { 2 - 5 } & $T_{\mathrm{P} \rightarrow \gamma},{ }^{\circ} \mathrm{C}$ & 780.1 & 781.7 & 780.9 \\
\cline { 2 - 5 } & $T_{\mathrm{F}+\mathrm{G} \rightarrow \gamma},{ }^{\circ} \mathrm{C}$ & 801.7 & 806.8 & 804.6 \\
\cline { 2 - 5 } & $T_{\mathrm{S}},{ }^{\circ} \mathrm{C}$ & 1115.2 & 1117.1 & 1118.2 \\
\cline { 2 - 5 } & $T_{\mathrm{E}},{ }^{\circ} \mathrm{C}$ & 1153.5 & 1138.5 & 1145 \\
\cline { 2 - 5 } & $H_{\text {melt. }}, \mathrm{J} / \mathrm{g}$ & 116.1 & 111.9 & 113.2 \\
\hline \multirow{5}{*}{ Cooling } & $T_{\mathrm{L}},{ }^{\circ} \mathrm{C}$ & 1177.5 & 1169.5 & 1167.8 \\
\cline { 2 - 5 } & $T_{\mathrm{E}},{ }^{\circ} \mathrm{C}$ & 1149.6 & 1146.2 & 1144.1 \\
\cline { 2 - 5 } & $T_{\mathrm{E}},{ }^{\circ} \mathrm{C}$ & 1136.4 & 1134.8 & 1125.2 \\
\cline { 2 - 5 } & $T_{\text {eutektoid }},{ }^{\circ} \mathrm{C}$ & 708.6 & 733.1 & 733 \\
\cline { 2 - 5 } & $H_{\text {solidif., }} \mathrm{J} / \mathrm{g}$ & 124.6 & 99.4 & 80.3 \\
\hline
\end{tabular}

The heating curve shown in Figure 4 indicates that the sequence of phase transformation and melting is as follows; at $693{ }^{\circ} \mathrm{C}$ the Curie temperature is recorded, followed by eutectoid transformation, where at $780.1{ }^{\circ} \mathrm{C}$ pearlite $\left(\alpha+\mathrm{Fe}_{3} \mathrm{C}\right)$ first starts to transform into austenite, and then at $801.7{ }^{\circ} \mathrm{C}$ the eutectoid transformation according stable phase diagram (Fe-C(Graphite)-Si), whereby the ferrite and eutectoid graphite, present on the existing graphitic particles, transform into austenite. The heating of austenite and graphite follows, whereby part of the secondary graphite dissolves in austenite (diffusion of carbon from graphite nodules into austenite). The solidus temperature is defined at $1115.2^{\circ} \mathrm{C}$. Considering the thermodynamic phase calculation in Thermo-Calc for
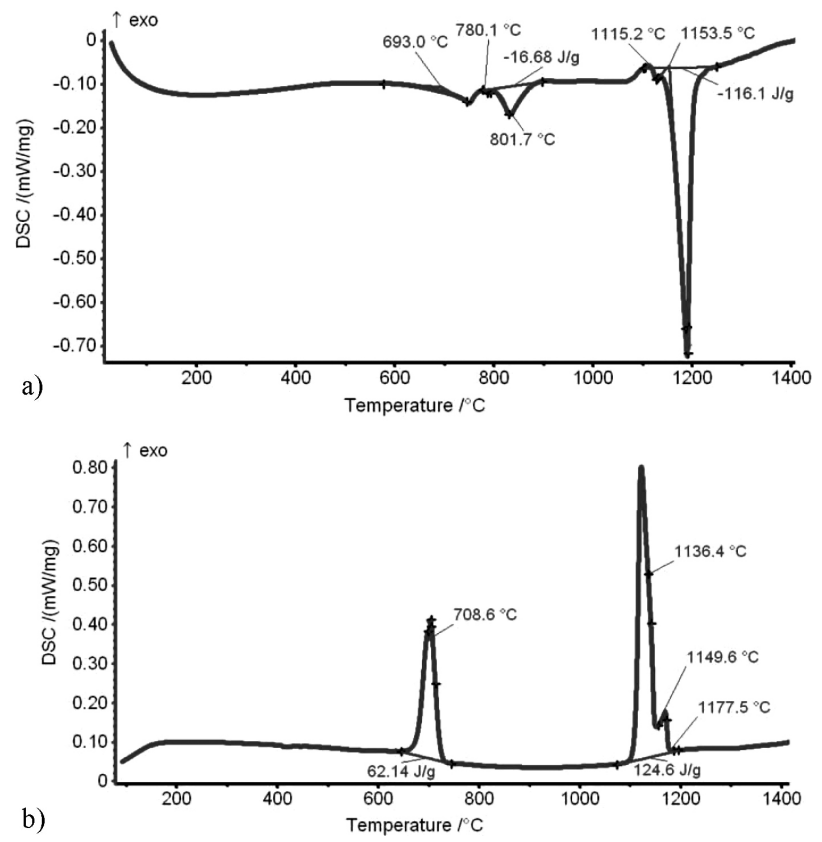

Figure 4: DSC curve: a) heating and b) cooling of sample 1-D1 

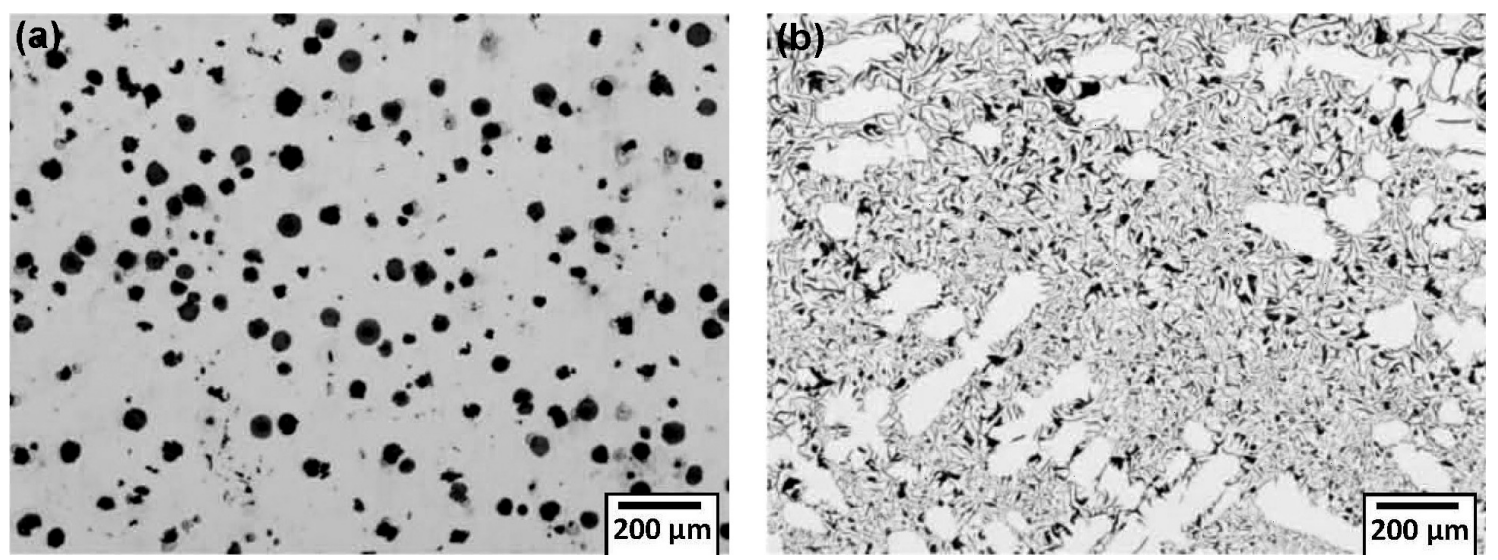

Figure 5: Microstructure: a) before and b) after DSC analysis of sample 1-D1
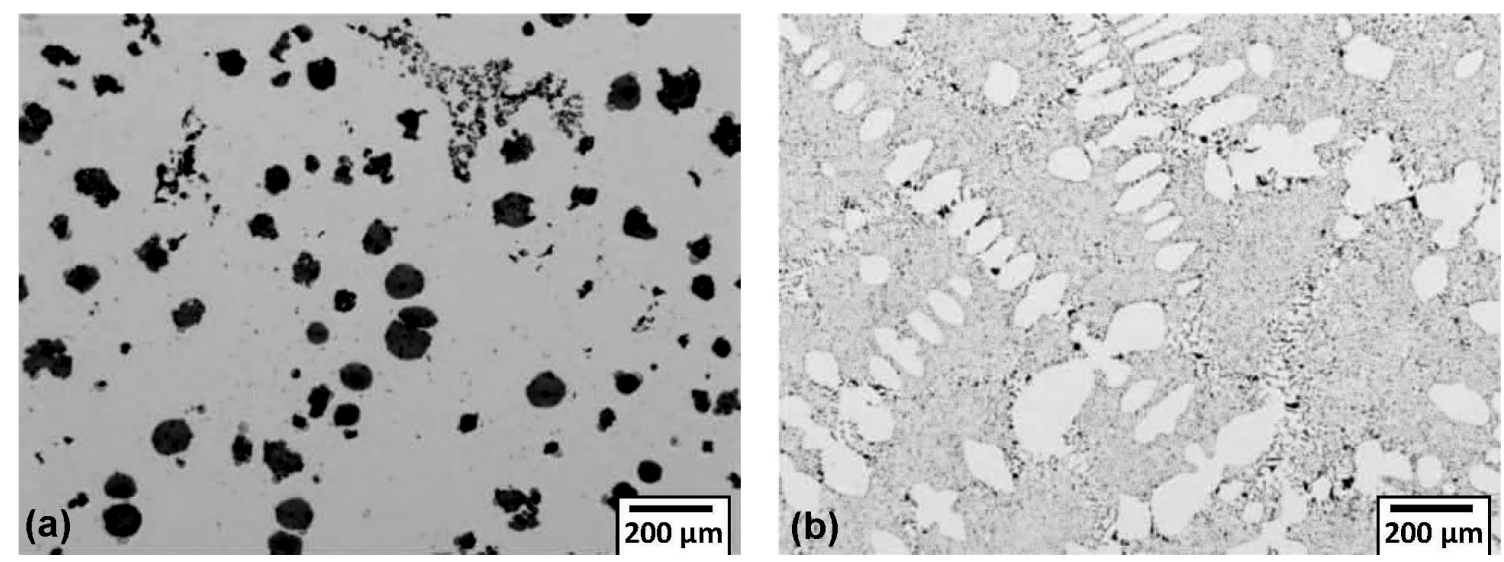

Figure 6: Microstructure: a) before and b) after DSC analysis of sample 1-D2
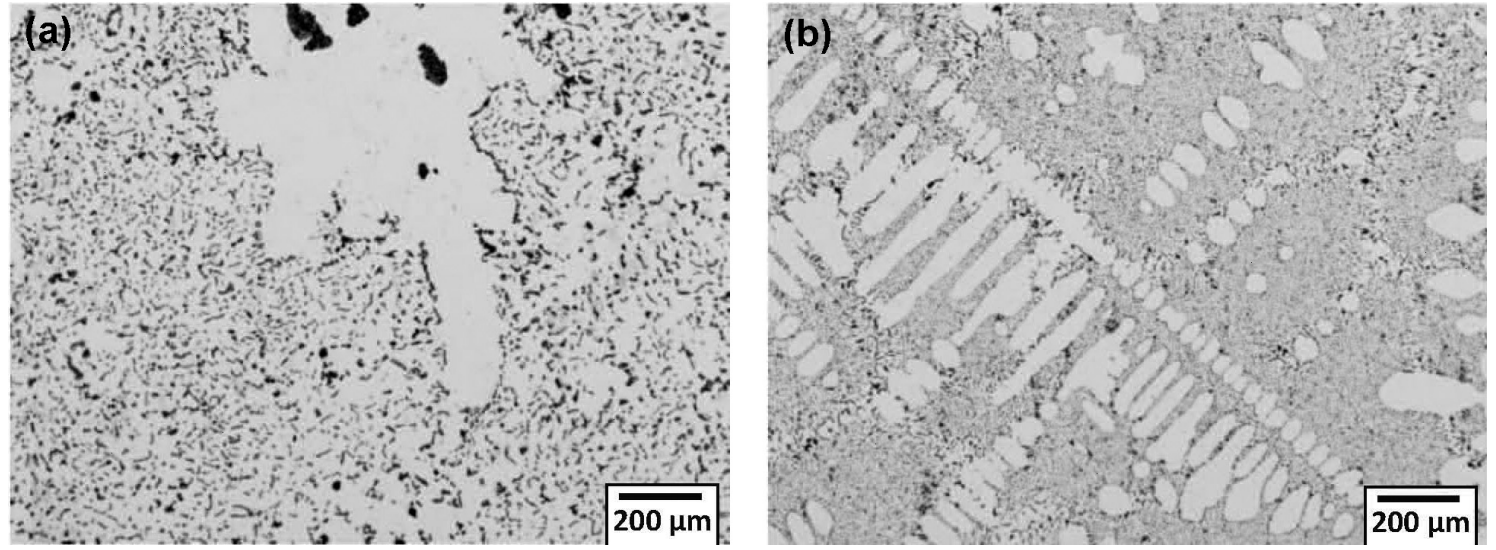

Figure 7: Microstructure: a) before and b) after DSC analysis of sample 1-D3

the given composition at this temperature, the eutectic begins to melt $\gamma+\mathrm{MgX}(\mathrm{X}=\mathrm{Si}$ and/or $\mathrm{S})$. The melting of this eutectic ends at $1153.5{ }^{\circ} \mathrm{C}$, followed by the melting of graphite eutectic $(\gamma+\mathrm{G})$ and melting of primary austenite crystals at the end. Thereafter everything assumes a liquid form and the heating of the melt starts.

Figure 4b shows the cooling curve for the same sample. From the cooling curve, it is first noticed the cooling of the melt. At $1177.5{ }^{\circ} \mathrm{C}$, the liquidus temperature $\left(T_{\mathrm{L}}\right)$ is recorded. At this temperature starts the crystallisation of primary austenite crystals and ends at
$1149.5{ }^{\circ} \mathrm{C}$. At $1136.4{ }^{\circ} \mathrm{C}$ the remaining melt solidifies into austenite and graphite. During eutectic solidification, $124.1 \mathrm{~J} / \mathrm{g}$ of latent heat is released. It is visible from the figure showing the corresponding microstructure (Figure 5b)) that the composition of the alloy is slightly hypoeutectic which is proved by the dendrite-shaped austenite regions. The eutectic morphology changes significantly after remelting. It is observed that the residual magnesium oxidation causes the formation of an undercooled form of graphite which has largely a lamellar morphology. The magnesium oxidation occurs 
despite the inert atmosphere of argon in the DSC testing device. At the end of solidification the cooling of the microstructure follows, which consists of primary austenite and eutectic $(\gamma+\mathrm{G})$. It is interesting to note that the second eutectic $(\mathrm{MgX}+\gamma)$ recorded on the heating curve was not recorded during the cooling of the same sample, which proves that the MgSi decomposed in $\mathrm{Mg}$ which oxidized and in Si which remained in the melt. At 708.6 ${ }^{\circ} \mathrm{C}$ starts the eutectoid transformation of both austenites (primary and eutectic) into ferrite and graphite and/or pearlite.

The heating and cooling curves of samples 1-D2 and 1-D3 are characterised by the existence of the same characteristic temperatures, which means that the sequence of phase transformations and melting/solidification of single phases is the same. Images of microstructure before and after testing are shown in Figures 6 and 7.

The results of the DSC analysis of samples of cone 2 are shown in Table 4. Beside the DSC analysis results, the images of microstructure in the initial phase and after testing are also shown, Figures $\mathbf{8}$ to $\mathbf{1 0 .}$

By analysing the heating and cooling curves of cone 2 samples, it has been observed that samples undergo the same phase transformations and melting/solidification sequence as the samples of cone 1 . The main difference to the samples of cone 1 is that the eutectoid transfor-
Table 4: Significant temperatures and enthalpies for cone 2, with $3.5 \%$ of the mass fractions of $\mathrm{Si}$

\begin{tabular}{|c|l|c|c|c|}
\hline \multirow{4}{*}{ Heating } & \multirow{2}{*}{ Parameter } & \multicolumn{3}{|c|}{ Sample } \\
\cline { 2 - 5 } & & 2 -D1 & $2-\mathrm{D} 2$ & $2-\mathrm{D} 3$ \\
\hline \multirow{5}{*}{ Cooling } & $T_{\text {Curie }},{ }^{\circ} \mathrm{C}$ & 711.3 & 712.7 & 710.4 \\
\cline { 2 - 5 } & $T_{\mathrm{P} \rightarrow \gamma},{ }^{\circ} \mathrm{C}$ & 851.5 & 853.3 & 853.7 \\
\cline { 2 - 5 } & $T_{\mathrm{F}+\mathrm{G} \rightarrow \gamma},{ }^{\circ} \mathrm{C}$ & & & \\
\cline { 2 - 5 } & $T_{\mathrm{S}},{ }^{\circ} \mathrm{C}$ & 1127.1 & 1126.9 & 1127.3 \\
\cline { 2 - 5 } & $T_{\mathrm{E}},{ }^{\circ} \mathrm{C}$ & 1148.7 & 1148.2 & 1144.6 \\
\cline { 2 - 5 } & $H_{\text {melt. }}, \mathrm{J} / \mathrm{g}$ & 109 & 107 & 125.4 \\
\hline \multirow{5}{*}{} & $T_{\mathrm{L}},{ }^{\circ} \mathrm{C}$ & 1179 & 1167.5 & 1169.6 \\
\cline { 2 - 5 } & $T_{\mathrm{E}},{ }^{\circ} \mathrm{C}$ & 1150.4 & 1148.2 & 1152.7 \\
\cline { 2 - 5 } & $T_{\mathrm{E}},{ }^{\circ} \mathrm{C}$ & 1131.8 & 1129.7 & 1131.7 \\
\cline { 2 - 5 } & $T_{\text {eutectoid }},{ }^{\circ} \mathrm{C}$ & 801.4 & 802.3 & 797.3 \\
\cline { 2 - 5 } & $H_{\text {solidif. }}, \mathrm{J} / \mathrm{g}$ & 122 & 89.6 & 132.2 \\
\hline
\end{tabular}

mation temperatures are shifted towards higher values as a result of high content of $\mathrm{Si}$ in cone 2. Likewise, the transformation peaks of pearlite and ferrite in austenite on the heating curve are less noticeable. As a matter of fact, these two peaks often overlap. ${ }^{17}$ This is why it is difficult to establish the exact temperature at the end of eutectic transformation of pearlite in austenite and at the beginning of the transformation of ferrite into graphite and austenite. During heating, also in cone 2, the exis-
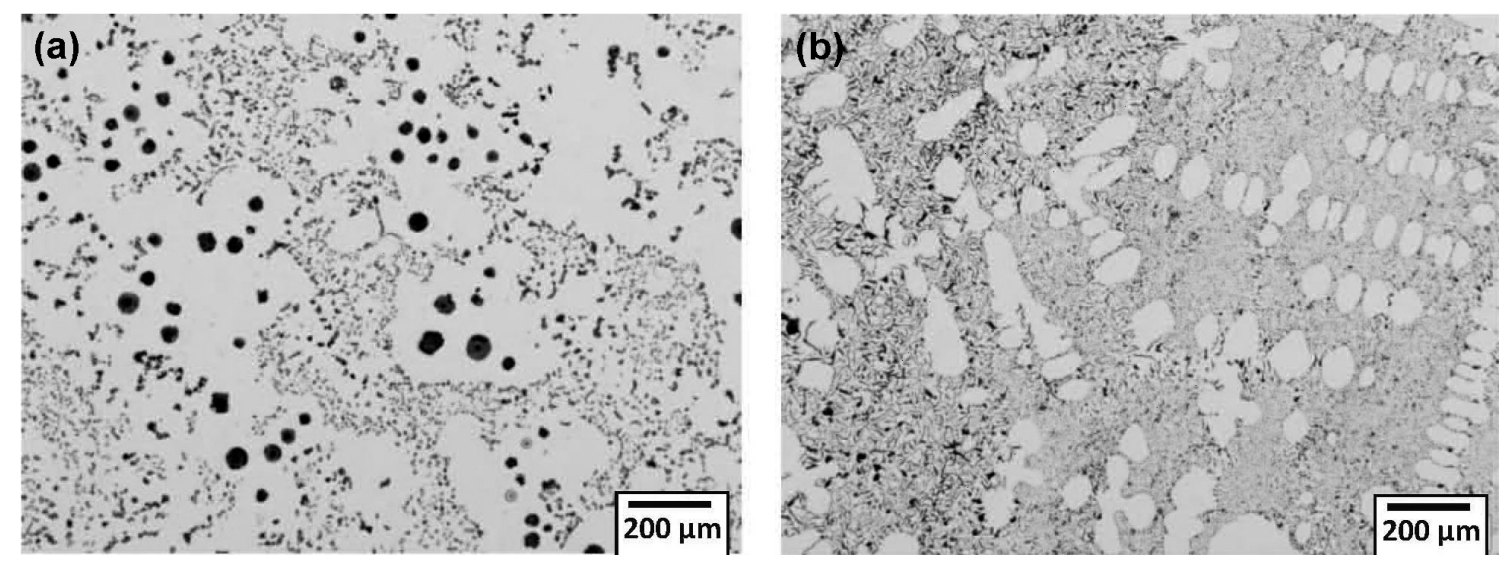

Figure 8: Microstructure: a) before and b) after DSC analysis of sample 2-D1
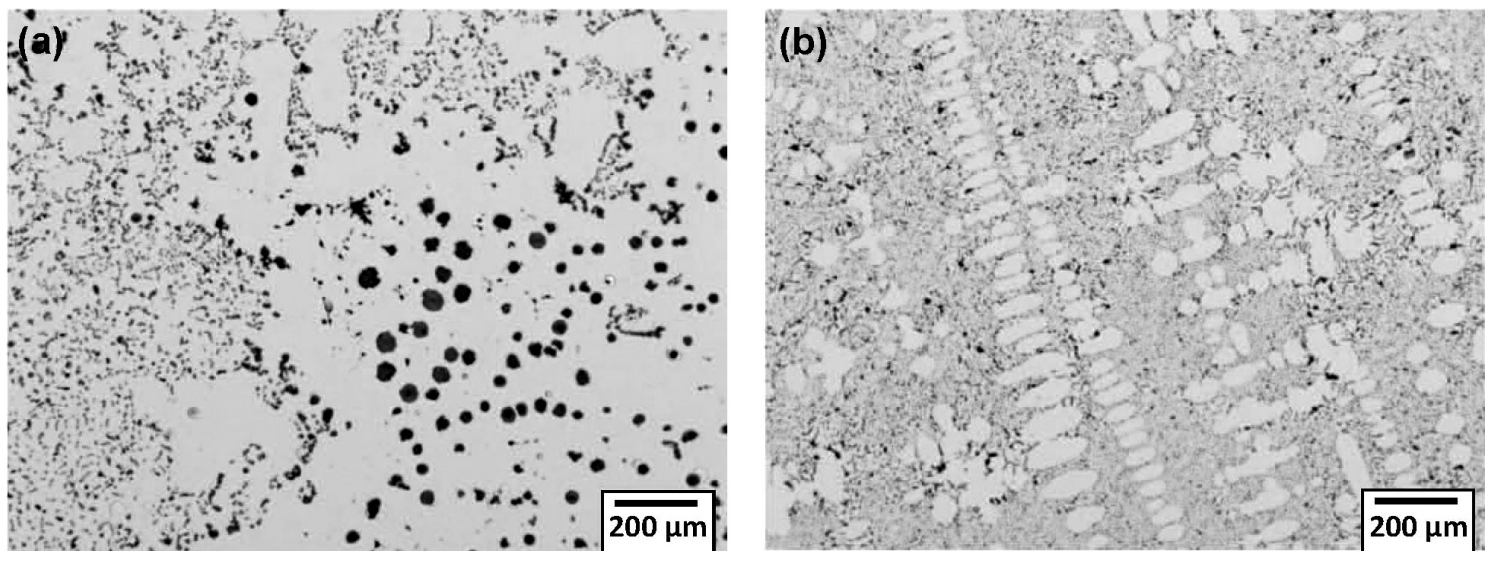

Figure 9: Microstructure: a) before and b) after DSC analysis of sample 2-D2 

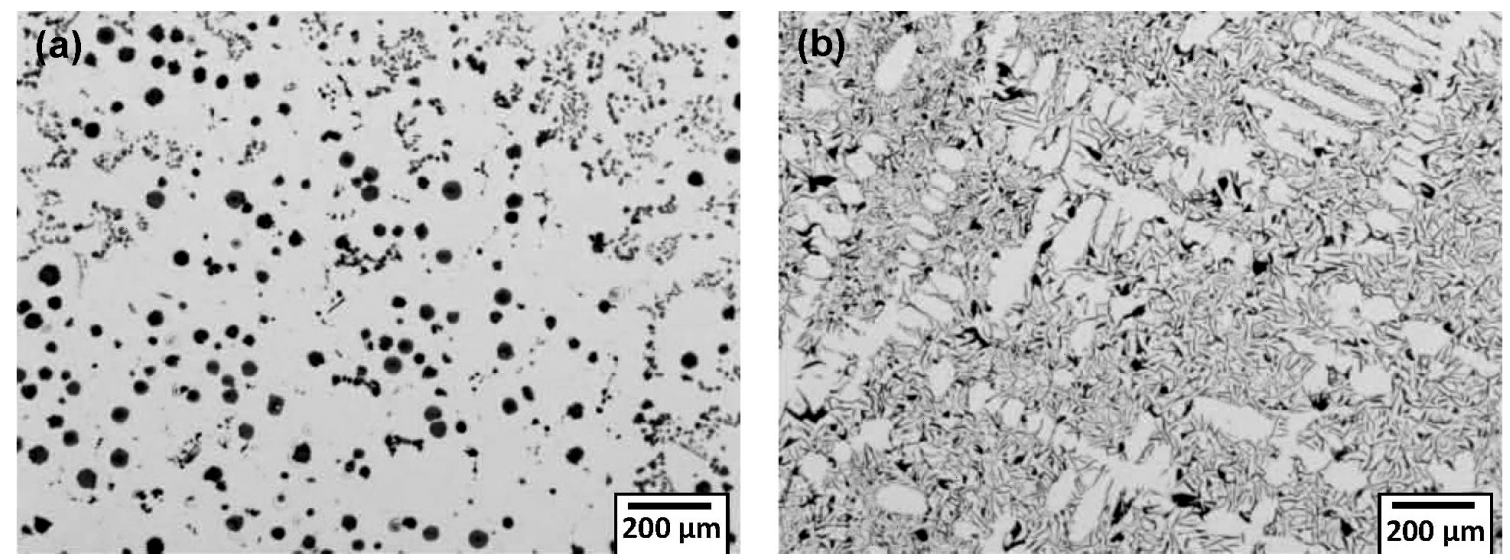

Figure 10: Microstructure: a) before and b) after DSC analysis of sample 2-D3

tence of the second eutectic has been noticed, which was absent during re-cooling.

\section{DISCUSSION}

From the heating results with reference to samples of cone 1 , it is visible that melting enthalpy differs slightly among samples with different cooling rates, Table 3. By comparing the cooling results for the same cone, it emerges that reference solidification temperatures shift towards lower values as the cooling rate decreases from the edge towards the centre. The latent heat released during solidification decreases significantly.

By examining the images of microstructure before the DSC analysis, it can be clearly observed that the content of chunky graphite in cone 1 with $0.7 \%$ of the mass fraction of $\mathrm{Ni}$ increases from the edge towards the centre. So the sample 1-D3, Figure 7a, shows practically a $100 \%$ of eutectic graphite with chunky graphite morphology, whereas the sample 1-D1, Figure 5a, has a microstructure of regular spheroidal graphite cast iron. In addition, different microstructures were obtained after the conducted DSC analysis. Microstructure consists of a primary dendritic austenite and a undercooled form of graphite with a certain content of irregularly distributed graphite accumulations. The undercooled graphite exhibits a coarse morphology in sample 1-D1, a mixed morphology (finer more than coarser undercooled graphite) in sample 1-D2, and the finest morphology in sample 1-D3. The finer the undercooled graphite, the smaller the graphite accumulations, Figures 5 to $\mathbf{7 b}$.

The difference in the microstructure of samples before and after DSC analysis occurs as a result of magnesium oxidation during reheating, which caused the absence of conditions for formation of the spheroidal graphite and the growth of graphite in the form of lamellar graphite in the undercooled form. The content of residual magnesium decreased to approximately $0.01 \% .^{18}$

Based on the results of DSC analysis and analysis of metallographic images of samples it can be concluded that the lower the enthalpy during solidification, the finer the undercooled graphite. In the sample 1-D3 with the finest morphology of undercooled graphite, the value of solidification enthalpy amounts to $80.3 \mathrm{~J} / \mathrm{g}$, in the sample 1-D2 it amounts to $99.4 \mathrm{~J} / \mathrm{g}$, and in the sample 1-D1 to $124.6 \mathrm{~J} / \mathrm{g}$ (spheroidal graphite before the analysis, that is, the coarsest graphite after the analysis). The same conclusion is valid for characteristic solidification temperatures. Table 3 shows also the temperature at the beginning of the eutectoid transformation $T_{\text {eutectoid }}$. In the sample 1-D1 with the lowest temperature $T_{\text {eutectoid }}=708.6{ }^{\circ} \mathrm{C}$, the lamellar morphology eutectic with the coarsest shape could be observed, Figure 5 b) (diffusion paths of carbon transport from austenite to graphitic particles are more distant compared to samples 1-D2 and 1-D3).

By comparing the heating results for samples of cone 2, Table 4, it can be seen that there is not much difference between the characteristic temperatures and melting enthalpy with reference to samples 2-D1 and 2-D2. The sample 2-D3 with respect to samples 2-D1 and 2-D2 has a significantly lower value of $T_{\mathrm{E}}$ and a higher value of melting enthalpy.

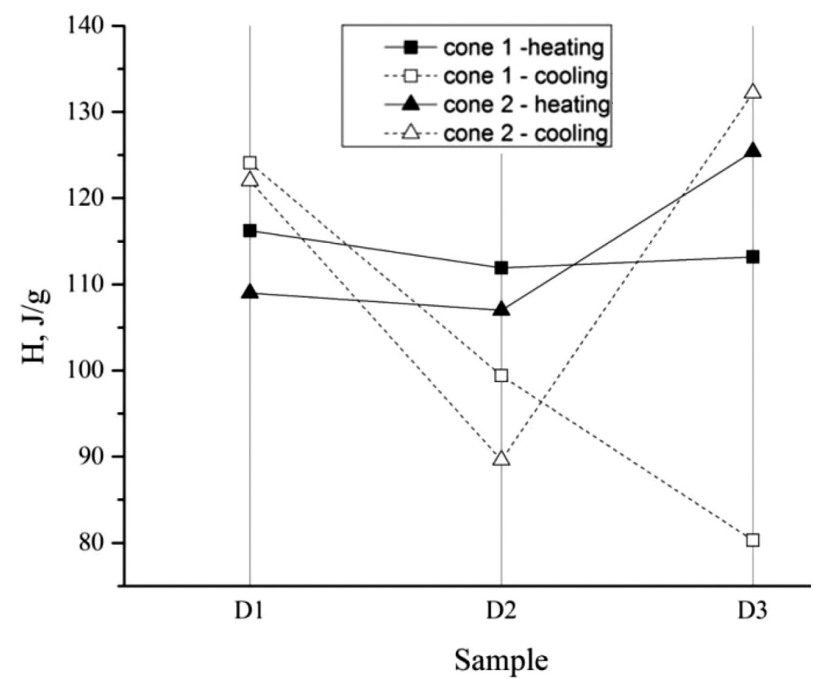

Figure 11: Comparison of enthalpies of melting and solidification of samples from cones 1 and 2 
By examining the microstructure images before the DSC analysis, it could be clearly observed that the content of chunky graphite in cone 2 with $3.5 \%$ of the mass fraction of $\mathrm{Si}$ does not increase from the edge towards the centre, but rather the opposite. In samples 2-D1 and 2-D2, before the conducted testing, the graphite eutectic has an equal share of spheroidal and chunky morphology, Figures 8a and 9a. In the sample 2-D3, before testing, graphite eutectic with spheroidal morphology prevails, whereas chunky graphite is present with a rather low share, Figure 10a, therefore the melting enthalpy differ compared to samples 2-D1 and 2-D2. $T_{\mathrm{E}}$ is lower for approximately $4{ }^{\circ} \mathrm{C}$, whereas $H_{\text {melt. }}$ is significantly higher, for approximately $16 \mathrm{~J} / \mathrm{g}$, as shown in Table 4.

By analysing the microstructure images it can be concluded that the microstructure of samples after cooling consists of primary austenite dendrites and graphite eutectic with morphology of undercooled lamellar graphite, Figures $\mathbf{8}$ to $\mathbf{1 0 b}$, as in cone 1. It is a slightly hypoeutectic alloy. The greater the presence of chunky graphite in the microstructure before the DSC analysis, the finer the undercooled graphite. In sample 2-D3, before testing, spheroidal graphite prevails, therefore after testing, the undercooled graphite is the coarsest.

The comparison of heating and cooling enthalpies for samples in both cones is shown in Figure 11. The values of enthalpies as well as the final microstructure hugely depend on the initial microstructure. The influence of the quantity of graphite eutectic with spheroidal morphology in the initial microstructure on melting and solidification enthalpies is observed. After melting and solidification of initial microstructure samples with greater content of graphite eutectic with spheroidal morphology a final microstructure with coarser undercooled graphite primarily of lamellar morphology is formed. As a consequence, and according to results obtained by testing samples of both cones, it follows that the solidification enthalpy at this microstructure is greater too. The differences in solidification enthalpy values are more pronounced compared to differences in melting enthalpy, in respect of changes in the graphite morphology.

\section{CONCLUSION}

Based on the results obtained in this study, the following main conclusions can be drawn:

- the obtained values of the melting and solidification enthalpy differ and depend on the initial microstructure of the samples.

- the higher the content of graphite eutectic with a spheroidal morphology before the DSC analysis, the greater the solidification enthalpy. Such a microstructure results after remelting in the formation of a coarser undercooled graphite of primarily lamellar morphology.

- the higher the content of chunky graphite or small graphite particles of irregular shape before remelting the lower the solidification enthalpy and the finer the undercooled graphite.

\section{Acknowledgements}

This work is partially supported by the foundry MIV d.d. Varaždin.

\section{REFERENCES}

${ }^{1}$ H. Löblich, Effect of nucleation conditions on the development of chunky graphite in heavy ductile iron castings, Giessereiforschung 58 (2006) 3, 28-41

${ }^{2}$ O. Knustad, L. Magnusson Åberg, Chunky Graphite, Effects and theories on formation and prevention, $14^{\text {th }}$ Inter. Foundry Conference, Opatija, Croatia, 2014

${ }^{3}$ R. Källbom, K. Hamberg, M. Wessen, L.-E. Björkegren, On the solidification sequence of ductile iron castings containing chunky graphite, Materials Science and Engineering A, 413-414 (2005), 346-351, doi:10.1016/j.msea.2005.08.210

${ }^{4}$ J. Lacaze, L. Magnusson, J. Sertucha, Review of microstructural features of chunky graphite in ductile cast irons, 2013 Keith Millis Symp. on Ductile Cast Iron, Nashville, USA, 2013, 360-368

${ }^{5}$ P. Ferro, A. Fabrizi, R. Cervo, C. Carollo: Effect of inoculant containing rare earth metals and bismuth on microstructure and mechanical properties of heavy-section near-eutectic ductile iron castings, Journal of Materials Processing Technology, 213 (2013), 1601-1608, doi:10.1016/j.jmatprotec.2013.03.012

${ }^{6}$ K. Hartung, O. Knustad, K. Wardenaer, Chunky graphite in ductile cast iron castings- Theories and examples, Indian Foundry Journal, 55 (2009), 25-29, doi:10.3969/j.issn.1003-8345.2009.02.010

${ }^{7}$ R. Källbom, K. Hamberg, L. E. Björkegren: Chunky Graphite - Formation and Influence on Mechanical Properties in Ductile Cast Iron, Proc. of the Gjutdesign 2005, Espoo, Finland, 2005

${ }^{8}$ M. Koch: Chunky Graphite; Effects and theories on formation and prevention, 2013 Keith Millis Symp. on Ductile Cast iron, Nashville, SAD, 2013, doi:10.1007/s11661-008-9731-y

${ }^{9}$ J. Riposan, M. Chisamera, S. Stan: Performance of heavy ductile iron castings for windmills, China Foundry, 7(2010) 2, 163-170

${ }^{10}$ M. Gagné, C. Labrecque: Microstrustural Defects in heavy section ductile iron castings: formation and effect on properties, AFS Transactions, 117 (2009), 561-571

${ }^{11}$ H. Itofuji, H. Uchikava: Formation Mechanism of Chunky Graphite in Heavy-section Ductile Cast Irons, AFS Transactions 90 (1990) 42, 429-448

${ }^{12}$ H. Nakae, S. Jung, H.-C. Shin: Formation mechanism of chunky graphite and its preventive measures, Journal of Materials Science \& Technology, 24 (2008), 289-295

${ }^{13}$ Z. Zhang, H.M. Flower, Y. Niu: Classification of degenerate graphite and its formation processes in heavy section ductile iron, Materials Science and Technology, 5 (1989), 657-664

${ }^{14}$ J. Zhou: Colour Metallography of Cast Iron - Spheroidal Graphite Cast Iron- Part III, China Foundry, 7 (2010) 1, 292-307

${ }^{15}$ J. Zhou, W. Schmitz, S. Engler. Untersuchung der Gefügebildung von Gußeisen mit Kugelgraphit bei langsamer Erstarrung, Giesserei-Forschung, 39 (1987) 2, 55-70

${ }^{16}$ R. Przeliorz, J. Piątkowski: Investigation of phase transformations in ductile cast iron of differential scanning calorimetry, Materials Science and Engineering, 22 (2011), 1-9

${ }^{17}$ F. Binczyk, A. Tomaszewska, A. Smoliński: Calorimetric analysis of heating and cooling process of nodular cast iron, Archives of Foundry Engineering, 7 (2007) 1, 25-30

${ }^{18}$ P. Mrvar, M. Trbižan, J. Medved: Investigation of cast iron solidification with dilatation analysis, KZT 33 (1999) 1-2, 45-49 